\title{
UNIão ESTÁVEL HOMOAFETIVA: ADPF 132 E A EFETIVAÇ̃̃o DA AUTONOMIA DA VONTADE ${ }^{189}$
}

\author{
Stable union homoafetiva: ADPF 132 effective and autonomy \\ of the will
}

Thays Fortes Borges

Graduanda em Direito pela Universidade do Oeste de Santa Catarina; Membro do Grupo de Pesquisa em Direitos Fundamentais Civis: Mecanismos de Efetivação dos Direitos Fundamentais nas Relações Privadas, sob a orientação do Dr. Matheus Felipe de Castro; do Programa de Pós-graduação em Direito Stricto Senso (Mestrado) da Universidade do Oeste de Santa Catarina; Bolsista de iniciação científica pelo Programa Institucional de Bolsas de Iniciação Científica (PIBIC).E-mail: thaysfortesborges@hotmail.com

\section{Matheus Felipe de Castro}

Professor Titular do Programa de Mestrado em Direitos Fundamentais da UNOESC - Universidade do Oeste de Santa Catarina, Professor Visitante da ESA/SC - Escola Superior da Advocacia de Santa Catarina, advogado e ex-vereador do Município de Florianópolis, Matheus Felipe de Castro é graduado em Direito pela UEM - Universidade Estadual de Maringá-PR (1999) e doutorado em Direito pela Universidade Federal de Santa Catarina (2009). E-mail: matheusfelipedecastro@gmail.com.

RECEBIDO EM: 29.04.2014 APROVADO EM: 25.06.2014

\section{Resumo}

A presente pesquisa aponta uma reflexão sobre a homossexualidade e os direitos dos casais homoafetivos. A necessidade de conhecer antes de julgar se aplica amplamente nesse quesito, por este motivo, abordamos o conceito histórico da homossexualidade e a formação dos pré-conceitos da sociedade em relação aos re-

$\overline{189}$ O presente trabalho é resultado do Grupo de Pesquisa Ordem Econômica, Constituição e Autonomia Privada do Programa de Mestrado em Direito da Universidade do Oeste de Santa Catarina - UNOESC. 
lacionamentos entre pessoas do mesmo sexo. Denota-se que o reconhecimento e a efetivação dos direitos dos casais homoafetivos representa um marco histórico na sociedade brasileira e que emerge do início de uma nova sociedade atualizada. O surgimento da união estável homoafetiva foi trabalhada sob a perspectiva de modalidade familiar que pode vir a ser convertida em casamento. Todo contexto foi analisado sob o viés do direito de escolha concernente ao exercício da autonomia da vontade e o respeito à dignidade da pessoa humana tutelada pelos direitos fundamentais, positivados na Constituição Federal de 1988. Para este fim analisou-se a decisão judicial ADPF 132 e ADI 144, que reconhece e elenca os pressupostos da união estável homoafetiva e também, o direito a seguridade social destes casais perpetrados para sustentar o ideal de sociedade igualitária e pluralista de direitos.

Palavras-chave: União estável homoafetiva. Autonomia da vontade. Princípios CONSTITUCIONAIS. Dignidade Da PESSOA humana.

\section{Abstract}

This research points to a reflection on homosexuality and the rights of homosexual couples. The need to know before judging it widely applies in this regard, therefore, approach the historical concept of homosexuality and training of pre -conceptions of society in relation to relationships between persons of the same sex. We denote that the recognition and realization of the rights of homosexual couples is a milestone in Brazilian society and emerging from the beginning of a new upgraded society. The emergence of stable homo-affective union was crafted from the perspective of family modality that may prove to be converted into a marriage. Every context was analyzed under the right of choice concerning the exercise of freedom of choice and respect for human dignity safeguarded by fundamental rights, positivized the 1988 Federal Constitution bias . To this end we analyzed the ruling ADPF ADI 132 and 144 , which recognizes and lists the assumptions of homo-affective stable marriage and also the right to social security perpetrated these to sustain the ideal of egalitarian and pluralistic society couples rights

Keywords: Stable union homoafetiva. Autonomy of the will. Constitutional PRINCIPLES. HUMAN DIGNITY.

SumÁRIO: Introdução. 1. Evolução histórica da homossexualidade e da união estável na sociedade. 2. Os princípios constitucionais e a efetivação da autonomia da vontade. 3. A decisão judicial ADPF 132 e ADI 4277: união estável homoafetiva uma conquista de direitos. 4. As parcerias homossexuais e o impacto da união homoafetiva no direito a pensão por morte. Conclusão. Referências. 


\section{INTRODUÇão}

O presente trabalho aponta uma reflexão em relação às modalidades de família, inserindo o relacionamento homoafetivo no âmbito do Direito. A partir de uma analise histórica, buscamos compreender a origem dos relacionamentos homossexuais e as diferentes reações da sociedade no decorrer do tempo. Atribui-se a mudança social e o processo de globalização como sendo o fator que afigura a quebra de tabus sociais, que hoje não encontram mais respaldo nos direitos fundamentais previstos na Constituição Federal de 1988.

A partir desse fato, a pesquisa trará um estudo acerca dos princípios constitucionais, que servem de fundamento para garantir e assegurar os direitos dos casais homoafetivos. Destaca-se que a identidade sexual não é requisito para justificar a discriminação. Assim, reconhecer o direito dos homossexuais, principalmente no que tange as relações homoafetivas é mister para sustentar o ideal de sociedade igualitária e pluralista de direitos. Ao discorrer sobre o princípio da liberdade, percebeuse que ser livre para optar é exercer sua autonomia da vontade, isto é, afirmar sua personalidade.

Tendo em vista que o principio da igualdade, assegura que todos são iguais perante a lei, não se deve privar ou diferenciar à custa da orientação sexual. Partindo dessa prerrogativa analisaremos a ADPF 132 e a ADI 2447 quanto aos votos e sua fundamentação, que sustentam uma importante decisão histórica na sociedade brasileira que é o reconhecimento da união estável entre casais homoafetivos.

\section{EvoluÇão HISTÓRICA DA HOMOSSEXUALIDADE E DA UNIÃo ESTÁVEL NA SOCIE- DADE}

Inicialmente a união entre duas pessoas fora do matrimônio era conhecida na sociedade e meio jurídico como concubinato. $\mathrm{O}$ concubinato designa o estado de "amasiamento" ou "ajuntamento" entre homem e mulher, estando intrínseco ao relacionamento sexual entre eles. Sucintamente abrange a união de duas pessoas com a finalidade de compartilhar suas vidas sem estabelecer vínculo de valores ultrapassados e patrimoniais. (FONTANELLA, 2006, p.25) Maria Berenice Dias (2003, p.178) aponta que a própria Constituição Federal elegeu o principio que sustenta a união estável, e este se refere ao afeto. Sendo assim a família passou a ser identificada pela presença do vínculo da afetividade.

A questão atual levantada pela união estável é o direito de liberdade de escolha quanto à opção sexual e o direito de compartilhar a vida com parceiro de mesmo sexo. Assim, faz-se necessário a homossexualidade e sua origem na sociedade. A palavra homossexual foi utilizada pela primeira vez no ano de 1869 pelo médico húngaro Karoly Benkert, e não obstante essa conduta de estabelecer relações com parceiros do mesmo sexo é tão antiga quanto à própria heterossexualidade. A busca

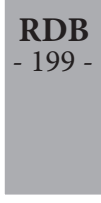


por entender e justificar esse comportamento é intenso.

Alguns acreditam que esse comportamento é originário de uma doença psíquica desencadeada por um desvio comportamental do indivíduo; para outros se trata de uma questão biogenética em que o indivíduo, seja homem ou mulher desenvolvem a homossexualidade no desenvolvimento intrauterino, nesse processo a quantidade de testosterona recebida pelo feto, pode determinar se o indivíduo em uma fase futura terá inclinação para o sexo oposto ou análogo ao seu, e ainda, para outros trata-se apenas de uma questão de escolha, uma orientação sexual onde o indivíduo tem o direito de decidir com quem quer se relacionar, seja com o sexo oposto, semelhante ou com ambos (FILHO; MADRID s/a, p.2).

Nas sociedades primitivas o amor entre os homens era uma prática constante e aceita por estar presente na cultura, lendas e mitos dos povos. Assim, por se tratar de um assunto amplamente cultural e com raízes primitivas, é praticamente impossível determinar uma explicação para a homossexualidade. Nas civilizações clássicas do mundo antigo, por exemplo, a importância não estava na sexualidade dos cidadãos, mas sim no status social com quem o cidadão se relacionava. Com isso percebe-se que a questão é muito mais ampla nesse aspecto do que as relações estabelecidas entre dois homens. (VECCHIATTI, 2008, p.41).

$\mathrm{Na}$ Grécia, o livre exercício da sexualidade fazia parte do cotidiano dos deuses, reis e heróis, portanto, não era considerada uma degradação moral, um acidente genético ou vício. Nesse sentido, um dos exemplos mais comuns é retratado pela cultura religiosa Hindu originária da Índia. É sabido que os deuses cultuados assumem diferentes formas relacionadas à sexualidade. Existem deuses bissexuais, hermafroditas, travestidos e até mesmo alguns que seriam capazes de mudar de sexo. É notável que independente dessas formas descritas, todos são muito valorizados e respeitados pela sociedade.

A visão indiana para o sexo não indicava somente a finalidade da procriação, mas sim a busca do prazer e do poder. Tendo em vista a importância atribuída aos deuses pela cultura indiana, é notável a influência que exerce sob a população, pois os instiga a agir de tal forma ou a manifestar conduta semelhante ao que é visualizado nos deuses. Nessa perspectiva a relação entre os semelhantes era natural, pois estava ligado exclusivamente ao misticismo, e a possível compreensão dos enigmas de seus deuses (FILHO; MADRID s/a, p.6)

Em Roma a prática homossexual também era algo que fazia parte do contexto social, esta prática era denominada sodomia. A sodomia era reconhecida como algo de procedência natural. Em ambas as civilizações tanto indianas quanto romana, há uma similaridade, o preconceito contra o ente passivo da relação; geralmente esse papel era incumbido às mulheres e escravos, todos excluídos do poder. Na conduta sexual em Roma a relação com a mulher era encarada apenas coma finalidade da procriação, por outro lado, com o homem era a manifestação da libido, um privilégio somente dos bem-nascidos. As relações homossexuais eram consideradas mais 
nobres do que a própria relação heterossexual. (DIAS, 2003, p.39).

O caráter relativo dos conceitos de masculinidade e feminilidade, segundo Vecchiatti (2008, p.47) são variáveis de acordo com a história e cultura de cada sociedade, não podendo ser visto como algo inalterável ou invariável. Tão somente com o surgimento do Cristianismo na sociedade é que a homossexualidade passou a conviver com o preconceito e a intolerância, pois até então o homossexual não era considerado diferente dos demais, e era uma prática aceitável.

O motivo da intolerância do cristianismo, é que a igreja consagrava o casamento que tivesse por finalidade a procriação como algo correto e moralmente aceitável, e passou a condenar toda pratica sexual que não se enquadrasse nessa condição. Com isso, na Idade Média ao invés de extinguir a prática da homossexualidade, acabou apenas tornando uma prática oculta. Em suma, a homossexualidade continuou a existir, a diferença é que passou a ser um ato efetuado com discrição e disfarçadamente, para que não fossem punidos pelo Estado, sob a influência da religião.

A conduta homossexual foi relacionada com a feitiçaria e o demonismo, através da igreja católica, e com o advento da peste negra que devastou a Europa essas afirmações ganharam força, e consequentemente a condenação homo fóbica também. (VECCHIATTI, 2008, p.55) As regras de estrita obediência à religião eram ditadas pela igreja, e em caso de descumprimento desses dogmas de fé o sujeito pecador seria sujeitado à ira divina, eterna e implacável (DIAS, 2003, p.41).

Somente com o afrouxamento dos laços entre o Estado e Igreja, é que se perdeu essa condição imposta pela religião, na medida em que novas mudanças sociais aconteceram consequentemente alguns tabus foram quebrados em relação à homossexualidade, ou seja, esse processo decorrente do tempo levaram ao surgimento de uma sociedade menos homo fóbica, e com o declínio da influência da igreja, o sentimento de culpa diminuiu e o prazer sexual deixou de ser criminoso.

O casamento que outrora era sacralizado pela igreja e pelo Estado, deixou de ser a única modalidade de formar família, e com isso novas estruturas emergiram. A orientação sexual fundada no afeto deixou de ser alvo de repúdio e caracterizou-se como uma opção e não algo ilícito ou que se deva atribuir culpa. Conforme Maria Berenice Dias (2003, p.42) desde meados da década de 60 e início dos anos 70, houve o aumento da visibilidade de diversas formas de expressão da sexualidade.

Para que se possa manter uma boa relação de convívio social, e assegurar à coletividade os mesmos direitos e deveres independente de pensamento, classes, religião e preferência sexual, é necessário manter uma relação de respeito mútuo, dando primazia aos limites, pois o direito de um indivíduo acaba, quando o de outro começa. 


\section{OS PRINCÍPIOS CONSTITUCIONAIS E A EFETIVAÇÃO DA AUTONOMIA DA VONTADE}

É indispensável nesse aspecto reconhecer que a sexualidade integra a condição humana, pois configura um elemento da natureza humana. Assegurar o respeito pela liberdade sexual e livre orientação sexual, arremete no realizar-se como ser humano, pois exercê-lo é a busca pelo alcance da felicidade. No viés dos Direitos Humanos, o direito a sexualidade conforme Maria Berenice Dias (2003, p.100) está lutando para ser inserido no âmbito dos direitos da terceira geração, que concernem aos direitos decorrentes da natureza humana, tomados genericamente e solidariamente.

É sabido que os pilares que outorgam a efetividade dos direitos humanos são os princípios do respeito à dignidade da pessoa humana, liberdade e igualdade, todos positivados na Constituição Federal de 1988. O direito a identidade sexual é um direito humano fundamental, logo o direito a união homo afetiva corresponde também a um direito humano fundamental (DIAS, 2003, p.101). Para Ingo Sarlet 2001 a dignidade da pessoa humana é uma qualidade intrínseca e distintiva de todo o ser humano.

A relação entre a proteção da dignidade humana e a orientação sexual é direta. A opção sexual representa o livre desenvolvimento da personalidade. Desta forma qualquer discriminação baseada na orientação sexual configura um desrespeito à dignidade humana, ferindo assim o maior princípio constitucional. Em relação ao princípio da igualdade é vedada pela Constituição qualquer desigualdade em razão de sexo. Teoricamente é positivada a proibição de discriminação em relação à orientação sexual, no entanto, o que se observa na prática é outra realidade. (DIAS, 2003, p.107).

Antes de analisar a relação entre o direito homo afetivo abrangendo a união estável e a autonomia da vontade é necessário estabelecer um paralelo conceitual referente a essa expressão tão conhecida na área dos direitos fundamentais. A palavra autonomia nos dicionários, diz respeito a uma qualidade ou condição inerente de um ser. O princípio da autonomia é "não escolher senão de modo a que as máximas da escolha estejam incluídas simultaneamente, no querer mesmo, como lei universal" (WALINE, 1945, p.169-170). Não obstante, a autonomia da vontade é um dos elementos essenciais para o exercício da liberdade, incide no âmbito das escolhas individuais, é o poder de se autogovernar, de decidir o que lhe cabe, e nesse caso, respectivamente a livre orientação sexual.

Também tanto a autonomia privada, quanto a autonomia da vontade ou autodeterminação, é considerada direitos fundamentais, que decorrem do mandamento descrito no art. $5^{\circ}$, caput, da Constituição Federal de 1988, ao assegurar essa condição para o princípio da liberdade. (BAEZ, CASSEL, 2011, p.230). A real eficácia dos atos de manifestação e declaração de vontade configura o exercício das liberdades vinculadas diretamente à personalidade. A liberdade enseja um valor essencial 
à condição humana, ela permanece como um direito de escolha até os dias atuais, sofrendo alterações apenas quanto as técnicas de tratamento implementadas pelo Estado. (BAEZ, CASSEL, 2011, p.325).

Desta forma, a liberdade quanto ao conteúdo, é caracterizada por não haver submissão a outrem, não estando sob o controle de terceiros e não sofrendo restrições impositivas, provenientes da sociedade ou do Estado. (BAEZ, CASSEL, 2011, p.325). Limitar a liberdade de escolha quanto à orientação sexual, é impor privação aos direitos que fundamentam um dos elementos principais da condição humana. Os limites ao direito de escolha, só poderão ser interpostos pela sociedade através das leis, quando isso interferir nos direitos da coletividade, isto é, visando proteção ao direito de todos. (BAEZ, CASSEL, 2011, p.329).

Efetivar a autonomia da vontade quanto aos direitos dos casais homoafetivos é simplesmente respeitar a liberdade de optar que cada indivíduo possui. A liberdade geral é, basicamente a permissão para fazer ou não fazer o que quiser, sendo que qualquer restrição a esse direito, deve estar devidamente assentada em lei. Partindo desses pressupostos, o direito geral de personalidade não permite influência do Estado na vida e tampouco na opção sexual do indivíduo. Deste modo devemse assegurar os direitos destes em constituir família com pessoa do mesmo sexo ou sexo oposto; a procriação natural ou assistida, a adoção ou mesmo o direito de não ter filhos. (DIAS, 2003, p.105)

O tratamento diferenciado, pela inclinação de um a outro sexo é evidência clara de discriminação a própria pessoa, é um desrespeito aos princípios constitucionais de igualdade, de liberdade de escolha e principalmente da dignidade da pessoa humana. Conforme pontua Contardo Calligaris, os direitos fundamentais valem para cada indivíduo singularmente, e para continuarmos exercendo nossa autonomia da vontade, é preciso defender e respeitar a liberdade do vizinho como se fosse a nossa.

Segundo DIAS (2003, p.105) há um caso semelhante que se aplica também a lógica dos homossexuais, que acontecera no tempo da escravidão, considerado como uma afronta ao princípio da liberdade é a proibição dos casamentos inter-raciais que vigorava em muitos países. Nesta proibição, os negros não eram proibidos de casar, porém, não poderiam se casar com pessoas de cor distinta a sua. Em contrapartida, a situação dos homossexuais é semelhante a dos negros, pois estes também podem se casar, entretanto, desde que não seja com pessoa do mesmo sexo. Até a decisão judicial ADPF 132, aqueles que não desejavam contrair matrimonio com o sexo oposto, eram privados do direito de constituir família dentro da legalidade.

Frente a toda essa analise, percebeu-se que o simples fato de respeitar resulta em evitar conflitos. Respeitar é demonstrar tolerância com terceiros, é admitir maneiras de pensar e agir diversas das suas próprias pontua Paulo Roberto Vecchiatti (2008, p.168). Portanto é evidente que subjugar a minoria em função do que a maioria pensa ser correto, é uma afronta à dignidade da pessoa humana. Ademais a homoafetividade não causa nenhum prejuízo aos heterossexuais, se ao vislumbrar 
um casal homossexual, um indivíduo heterossexual se sente incomodado, isso é um profundo preconceito injustificável.

Portanto, se o direito de se autogovernar compete no exercício do princípio da liberdade positivado na constituição, logo é evidente que autodeterminar a forma como viver a vida é assegurar o cumprimento desse princípio. Aparentemente o ser humano parece ter dificuldade de aceitar aquilo que não consegue compreender, por ser diferente, e consequentemente, por não estar acostumado a lidar com a situação. Por este motivo, os grupos minoritários da sociedade são comumente discriminados pela grande maioria. Assim, é dever do legislador garantir a essas minorias, mecanismos legais específicos, para que possam ingressar no judiciário contra o ofensor que tenha desrespeitado seus direitos. (VECCHIATTI, 2008, p.164).

\section{A deCisão JUdicial ADPF 132 e ADI 4277: UNiño eSTÁVEl hOMOAFETIVA UMA CONQUISTA DE DIREITOS}

A Constituição Federal de 1988 é o marco inicial em eleger o afeto como princípio fundamental de uma união estável, através disso, a família passou a ser compreendida não só por laços sanguíneos, mas também pelo laço de afeto que existe em uma relação. Também, a Constituição atual foi mais além, assegurou o direito à igualdade, proibindo qualquer espécie de discriminação, inclusive em razão de sexo, embora não determine de forma expressa a união homossexual, ela o faz implicitamente. (DIAS, 2009, p.179).

O problema de não se determinar expressamente todas as modalidades de famílias no texto constitucional, segundo Paulo Lobo (2002, p.92) é hermenêutico, uma vez que a interpretação sistemática da carta constitucional conduz a ideia de inclusão das outras modalidades familiares. Sendo assim, nada mais é, do que um equivoco excluir as uniões homoafetivas do âmbito das entidades familiares, em razão da expressão "homem e mulher", destacado no art.226 $\S 3^{\circ}$ da Constituição Federal de 1988. Entende-se que se duas pessoas estabelecem convívio social, cumprindo os deveres de mútua assistência, fundamentados pelo amor e respeito, nada impede que se deixe de reconhecer direitos ou mesmo impor obrigações recíprocas. (DIAS, 2009, p.181).

Cristiano Chaves de Farias relembra que as modalidades de família casamentaria - fundada no casamento; união formal - entre pessoas de sexo oposto e convivencial - união estável entre sexo oposto, não se confundem com a família homoafetiva, haja vista, que esta modalidade configura um modelo familiar autônomo, como as comunidades de entre irmãos, tios e sobrinhos, avós e netos, que merecem proteção especial do Estado. Com a finalidade de oferecer a proteção a essa nova modalidade de instituição familiar o Governador do Estado do Rio de Janeiro, Sérgio Cabral impetrou a Arguição de Descumprimento de Preceito Fundamental 132, visando o reconhecimento da união estável homoafetiva pelo Supremo Tribunal 
Federal. (VECCHIATTI, 2008, p.329).

Nesta decisão enfatizou-se a violação de preceitos constitucionais fundamentais já analisados anteriormente. O primeiro deles é o princípio da igualdade, onde é vedada toda forma de preconceito e discriminação irrazoável, o que abrange concomitantemente a orientação sexual das pessoas de maneira implícita. Afirmouse que é desnecessário elencar razões para impedir o tratamento diferenciado, uma vez que em um Estado democrático e pluralista, tais motivos devem ser pautados por argumentos de razão pública e não visões particulares, e o fato do não reconhecimento estariam violando diretamente o propósito constitucional de construir uma sociedade pluralista e refratária de preconceito, sendo então os argumentos religiosos inadmissíveis, por se tratarem de visões de mundo particulares. (VECCHIATTI, 2008, p.330).

Luís Roberto Barroso afirmou também que a união estável visa respeito e apoio mútuos e não respectivamente a procriação, que caso exigido, deveria servir para negar o reconhecimento aos casais estéreis ou mesmo àqueles que não desejam ter filhos, o que na prática de fato não acontece. O segundo preceito constitucional de grande relevância corresponde ao direito à liberdade e a autonomia da vontade, decorrente à autonomia privada. Um Estado Democrático de Direitos deve assegurar aos seus indivíduos o direito de escolha entre diferentes projetos de vida, desde que estes sejam lícitos, e propiciar condições efetivas para que se possa concretizar tais feitos. (VECCHIATTI, 2008, p.330).

Em relação à questão de escolha da orientação sexual, não indica o estabelecimento de relações com indivíduos do mesmo sexo ou sexo oposto, mas sim em se abster de sua orientação sexual ou vive-la clandestinamente, isto é, de forma oculta; sendo que as pessoas deveriam ter liberdades individuais que não podem ser cerceadas pela maioria de acordo com Paulo Roberto Vecchiatti (2008, p.330). Exercer a autonomia da vontade é ser livre para optar, a liberdade é um pressuposto para o desenvolvimento da personalidade, privar um indivíduo de viver a sua orientação sexual em todos os seus desdobramentos é privá-lo de uma das dimensões que norteiam o sentido da existência. Denota-se que a autonomia privada só pode ocorrer baseada no princípio da razoabilidade e proporcionalidade.

O terceiro princípio constitucional enfatizado na ADPF 132 é a primordial dignidade da pessoa humana, conforme Immanuel Kant o ser humano deve ser tratado como um fim em si mesmo e não como um meio, haja vista que todos os projetos de vida pessoais ou coletivos, quando razoáveis, são dignos de respeito e consideração. Ou seja, são merecedores de igual reconhecimento, o não-reconhecimento das uniões homo afetivas implicam na violação de dois núcleos da dignidade da pessoa humana conforme aponta Paulo Roberto Vecchiatti (2008, p.331). O primeiro diz respeito ao ser humano ser tratado como um meio, no projeto de vida determinado pela sociedade, onde só é aceito aquele que se molda pela tradição, respectivamente no que tange ao papel de membro da família heterossexual destinado a procriação. 
O segundo núcleo da dignidade da pessoa humana a ser violado pelo não reconhecimento é afirmar que esse estilo de vida não merece ser tratado com a mesma dignidade e consideração atribuída aos demais, conceituados corretos pela tradição da sociedade. Esse fato converte em desconforto por parte dos adeptos, pois estes negam sua própria identidade à custa de um grande sofrimento emocional, esta situação elenca a verdadeira política de discriminação. O quarto princípio constitucional sustentado na argumentação em prol da decisão favorável frente à união estável homo afetiva é o princípio da segurança jurídica, por não estar incluído no regime jurídico, arremete na insegurança jurídica.

O Direito é visto como o mecanismo regulamentador da sociedade, e através da positivação em lei, aquele que tem seu direito lesado pode buscar ressarcimento das consequências, sejam morais ou físicas, pleiteando ação contra o ofensor, ao passo que a união homo afetiva não possuía embasamento jurídico, como poderia ser buscado o direito dos homossexuais na questão de relações conjugais? A partir desses princípios foi feito o julgamento da ADPF 132 e ADI 4227, cuja decisão foi um resultado positivo.

O ministro Ayres Britto justificou seu voto equiparando a união estável com as uniões homoafetivas, e ressaltou que não se deve fazer uso da letra da Constituição Federal para "matar o seu espírito", isto é, percebeu-se que alguns direitos estão implícitos em relação à Carta Constitucional. Afirmou ainda "que não se deve separar por um parágrafo, o que a vida uniu pelo afeto, em clara remissão ao art. 226, par. $3^{\circ}$ da Constituição Federal". O Ministro relator também manifestou opinião sobre a adoção a casais homoafetivos, firmando que a orientação sexual dos adotantes, não é importante, desde que analisado o real interesse do casal em realizar a adoção. (CHAVES, 2011).

O segundo votante do julgamento foi o Ministro Luiz Fux discorreu sobre a temática da homossexualidade, afirmando que é um fato da vida, além de constituir uma orientação e não opção sexual. Enfatizou que as relações estabelecidas entre casais do mesmo sexo constituem vínculos contínuos e duradouros, baseados em respeito e afeto recíproco, para partilhar meios e projetos de vida. Também apresentou dados do último censo que apontam a existência de mais de 60 mil casais homossexuais no Brasil. Com isso firmou seu voto favorável à união estável homo afetiva. (CHAVES, 2011).

Em seguida a Ministra Carmem Lúcia, terceira a votar, acompanhou os votos dos dois Ministros que anteriormente haviam votado: Min. Ayres Britto (relator) e Min. Luiz Fux. No voto da Ministra, não obstante, ficou claro a postura consensual da corte em repreender o preconceito e a discriminação, firmou seu voto embasando na seguinte expressão: "todas as formas de preconceito merecem repúdio de todas as pessoas que se comprometam com a justiça, com a democracia, mais ainda os juízes do Estado Democrático de Direito". A ministra também relembrou o caminho trilhado pela jurisprudência dos tribunais estaduais, em busca de assegurar os direitos dos 
casais do mesmo sexo, finalizou o voto, desta forma julgando procedentes as duas ações constitucionais. (CHAVES, 2011).

O Ministro Ricardo Lewandowski foi o quarto Ministro do Supremo Tribunal Federal a votar favoravelmente, para fundamentar, apresentou inicialmente um parâmetro entre o conceito de família trazido pelas constituições anteriores, evidenciando a relação que existia entre a ideia de família e o instituto do casamento, que desapareceu na Constituição Federal de 1988. Com isso, julgou procedentes as duas ações constitucionais, vislumbrando o reconhecimento da união homo afetiva como entidade familiar. O ministro Joaquim Barbosa, quinto a votar, julgou procedente as ações, porém foi divergente em relação a fundamentação. (CHAVES, 2011).

O sexto ministro a votar foi Gilmar Mendes, acompanhando o voto dos demais ministros, também foi favorável a decisão, pois considerou que era dever do Supremo Tribunal Federal assegurar o direito da minoria e, por conseguinte, dos direitos fundamentais. A Ministra Ellen Gracie, sétima a votar no julgamento da ADPF 132 e ADI 4277 acompanhou na integralidade o voto do Ministro Relator. Relembrou processos judiciais que ocorreram em outros países, e que despertaram a possibilidade de se efetivar o casamento homo afetivo. O Ministro Marco Aurélio firmou seu voto discorrendo sobre a realidade homossexual, e sobre a importância de assegurar direitos que erradiquem os crimes homo fóbicos. (CHAVES, 2011).

Por fim o Ministro Celso de Mello acompanhou o voto do Ministro Relator, Ayres Britto, julgando procedentes as ações constitucionais, objetivando reconhecer como entidade familiar, a união homo afetiva, desde que sejam atendidos todos os requisitos exigidos para a união estável entre homem e mulher, e assegurando aos cônjuges os mesmos direitos e deveres. (CHAVES, 2011). Sendo assim, todos 10 ministros votantes no julgamento da ADPF 132 e da ADI 4277 foram favoráveis as ações constitucionais, reconhecendo a união homo afetiva como entidade familiar, sob o mesmo regime que se aplica à união estável entre homem e mulher.

Perceberam-se a divergência entre as fundamentações, algumas regidas pela própria Constituição Federal e outras embasadas na analogia da moral voltadas ao entendimento do ser social. Contudo, atendeu-se ao pedido principal, a partir da efetivação das ações pleiteadas foi instituída a união estável homo afetiva e declarado o regime jurídico da união estável aplicável ás uniões homo afetivas, com decorrência direta dos preceitos fundamentais de igualdade, liberdade, dignidade e segurança jurídica. (VECCHIATTI, 2008, p.334).

\section{As PARCERIAS HOMOSSEXUAis E O IMPACTO DA UNIÃo HOMOAFETIVA NO DIREI- TO A PENSÃO POR MORTE}

As parcerias homossexuais tanto na doutrina quanto na jurisprudência vêm sendo conhecidas como sociedade de fato. Isto é, um fato social e jurídico gerador de efeitos jurídicos. De modo que configura também uma sociedade civil, e comunhão 
de interesses (BRANDÃO, 2002, p.101). Tradicionalmente o direito Previdenciário é inovador, pois foi ele quem reconheceu o direito da concubina, por exemplo. E no que tange à homossexualidade, deveras, não poderia ser diferente. É fato que o desamparo da pessoa que vivia em parceria homossexual, após a morte ou prisão do parceiro, de quem era economicamente dependente, trouxe consequências desastrosas, tanto no ponto de vista econômico, quanto emocional e afetivo.

A partir da conquista dos direitos positivados através do reconhecimento da união estável homoafetiva, a questão do desamparo dos companheiros passou a ser tratada juntamente com novas pretensões relacionadas diretamente com a formação dessa nova modalidade de família, que diz respeito aos direitos direcionados ao cônjuges em determinadas situações, onde compete a previdência social ressarcir os indivíduos. Conforme pontua Martins (2011) O ano de 2011 ficou marcado para Previdência Social, pois "por intermédio da ação dos Tribunais Superiores, uma das questões mais delicadas relativas à concessão de benefícios previdenciários, em especial o destinado aos dependentes do segurado falecido, no caso, a pensão por morte".

A sociedade atual, sem dúvida apresentou inúmeros avanços no que tange os direitos dos casais homossexuais, porém ainda há muito preconceito quanto à aceitação dos direitos referentes aos casais homossexuais. Em princípio, não deveria ser tão difícil de ser instituído de acordo com o que é proposto para casais de sexos diferentes. No entanto, determinar direitos nessa esfera pode ser um grande desafio. Baseado no principio da igualdade, sem dúvida a seguridade social é um direito que deve surtir efeitos para todos, independente da condição sexual adotada. (BRANDÃO, 2002, p.106).

Afirmar direitos aos parceiros de relações homossexuais é assegurar-lhes a seguridade social. Segundo Alfredo J. Ruprecht (1996, p.40) "a seguridade social é um instrumento protetor, preventivo e assistencial, cujo objetivo é amparar os membros da sociedade de qualquer contingência social, seja ela material ou espiritual". Entende-se nesse aspecto, que a seguridade social inclui não só o amparo econômico para as necessidades básicas, mas também, o bem-estar psicológico do parceiro. Há que se considerar que a seguridade social é um fator poderoso de equilíbrio socioeconômico e é dever do estado trilhar a proteção assistencial gerada pelos infortúnios da vida.

A discussão levantada em relação aos direitos previdenciários dos casais homoafetivos, é principalmente a pensão por morte do companheiro do mesmo sexo. Tal discussão foi levada aos Tribunais Pátrios, cabendo ao juízo da $3^{\mathrm{a}}$ Vara Federal de porto Alegre, proferir a decisão pioneira na Ação Civil Pública ${ }^{\circ}$ 2000.71.00.0009347-0, tendo por finalidade conceder ou não o benefício de acordo com o Regime Geral de Previdência Social, estendendo os efeitos para além do julgamento, isto é, sendo aplicável também às demais demandas administrativas existentes referentes ao mesmo caso. (MARTINS, 2011). 
O fundamento de violação ao dogma constitucional, referente à dignidade da pessoa humana e afronta ao princípio da igualdade constituiu a justificativa para instaurar a ação. Deste modo, foi concedida a tutela antecipada, com abrangência nacional, para que o órgão previdenciário principal federal possibilite a inscrição do companheiro como dependente principal, garantindo assim o auxílio-reclusão e pensão por morte do beneficiário, desde que cumpridas às exigências que também são exigidas aos companheiros heterossexuais (DIAS, 2009, p.188).

A repercussão da decisão proferida pelo douto Juízo Federal repercute com magnitude, haja vista que surtiu efeito, levando o INSS a reconhecer, por instrução normativa, o direito a pensão por morte para aqueles que mantinham uma relação homoafetiva. Entretanto, para tornar efetivo o recebimento, o possível beneficiário deve demonstrar que o falecido contribuía efetivamente para o seu sustento. A hipótese de aplicação segundo Martins (2011) pode ser equiparada a Teoria Tridimensional do Direito, elaborada por Miguel Reale, cuja união estável homoafetiva foi reconhecida pela sociedade como algo relevante, ou de alto valor social e por isso há a necessidade se uma regulamentação ou normatização.

A Previdência Social reconhece o direito para os óbitos ocorridos a partir de 05 de abril de 1991, ao benefício de pensão por morte aos parceiros homossexuais que comprovem união estável. O dependente deve apresentar, além dos documentos pessoais, três provas materiais, como mesmo endereço, conta bancária conjunta, seguro de vida, seguro saúde, bens imóveis ou outros documentos que comprovem a união do casal. Inicialmente através da IN 25/2000 Revogada, preceituava em seu art. $3^{\circ}$ vários documentos exigidos especificamente para parceiros de relações homossexuais, sendo que tal exigência era muito mais rígida do que a prevista para casais heterossexuais. (BRANDÃO, 2002, p.108).

Independentemente de a união ser homo ou heterossexual, as condições para o dependente requerer a pensão por morte são as mesmas conforme já citado. É necessário apresentar, no mínimo, três documentos que comprovem a união estável com a companheira ou companheiro falecido (a), como, por exemplo, a declaração de Imposto de Renda do segurado constando o beneficiário na condição de dependente, testamento ou conta bancária conjunta. (BRASIL, 2005).

Também o INSS aceita outras declarações, desde que estas evidenciem a união estável do casal, como o comprovante do mesmo domicílio, procuração, fiança reciprocamente outorgada, registro em associação de qualquer natureza desde que conste o interessado como dependente do segurado, anotações em ficha ou livro de registro de empregado, apólice de seguro na qual o segurado é o instituidor e o interessado (a) beneficiário, ficha de tratamento médico sendo o segurado responsável, escritura de compra e venda de imóvel pelo segurado em nome do dependente ou outros documentos que comprovem a união. (BRASIL, 2005).

Em relação à pensão por morte, a Previdência Social considera dependentes do segurado aquelas pessoas que dele dependem economicamente. Para fins 
previdenciários, esses dependentes são classificados em três categorias por ordem de prioridade: o cônjuge, o companheiro (a) e filhos menores de 21 anos, não emancipados ou maiores inválidos; os pais, e, por último, os irmãos menores de 21 anos, não emancipados ou maiores inválidos. Havendo dependentes de uma classe, os integrantes da classe seguinte perdem o direito ao benefício. (BRASIL, 2005).

Seguindo essas classes de beneficiários, todo casal homossexual está apto a solicitar benefícios do INSS. "Os homossexuais também contribuem, eles também têm o direito e eles participam da sociedade. Nada mais justo que eles também venham a usufruir dos benefícios da Previdência Social", diz a chefe da Agência da Previdência Social (APS) Relógio de São Pedro, Angélica Amaral. (Lissandra Pires)

A Justiça Federal e o próprio Superior Tribunal de Justiça já vêm reconhecendo tanto o direito de pensão por morte, quanto à inscrição de parceiro em plano de assistência médica. Mesmo na hipótese de outros beneficiários, a Justiça Federal Gaúcha reconhece ao parceiro homossexual o direito a pensão vitalícia, a ser repartida em partes iguais com a ex-cônjuge do servidor falecido. (DIAS, 2009, p.191). Nos dias de hoje o direito previdenciário aos homossexuais tem evoluído significativamente, ensejando fixar os ideais dos princípios constitucionais de igualdade, liberdade, dignidade da pessoa humana e a seguridade social.

\section{Conclusão}

A presente pesquisa analisou o direito dos casais homoafetivos sob a perspectiva de modalidade familiar e como uma condição necessária para o pleno exercício dos princípios constitucionais associados a esta prerrogativa. Percebeu-se que apesar dos avanços da sociedade, o preconceito social em relação a estes casais ainda faz parte do contexto social, sendo assim, o desafio é dar voz àqueles que têm seus direitos privados por meio da proteção judicial. Foram analisadas as relações homossexuais na sociedade antiga e nos dias atuais, vinculando a relação homoafetiva como uma nova modalidade de família.

Foram trabalhados os princípios constitucionais da igualdade, liberdade e autonomia da vontade relacionados como fundamento para o reconhecimento dos direitos dos parceiros homossexuais, considerando principalmente a liberdade de escolha como um dos elementos que compõem a condição humana e que fazem parte da personalidade e dignidade da pessoa humana. Em relação à efetivação da autonomia da vontade, eis que a ADPF 132 e a ADI 4227 trouxeram à tona uma nova realidade para o ordenamento jurídico ao reconhecer e tutelar a união estável entre casais homoafetivos.

O reconhecimento da união estável homoafetiva, fundada nos princípios constitucionais e no afeto como elemento essencial para constituir família, efetivou o direito dos parceiros homossexuais em compartilhar suas vidas em união, com a proteção legislativa. A decisão judicial reconheceu os direitos de união estável aos 
homossexuais, tais quais igualmente para os heterossexuais, rompendo assim o caráter discriminatório. É fato que toda decisão implica em efeitos na esfera jurídica, nesse respeito, foi feita a analise dos efeitos judiciais dessa decisão na esfera do Direito Previdenciário.

O direito previdenciário é alicerce para garantir a seguridade social, nesse sentido, salientamos o direito pensão por morte ou prisão do companheiro, como aspecto principal em assegurar a seguridade social para os companheiros, uma vez que é um direito que também cabe aos casais heterossexuais. Alguns tribunais já autorizam essa pensão com fundamento legislativo, no entanto, conforme observado há a presença dos requisitos também necessários para os casais heterossexuais, que busquem comprovar a dependência financeira do parceiro falecido ou detento.

Tais elementos de reconhecimento da união estável homoafetiva e posterior tutela à seguridade social dos casais homoafetivos, evidencia uma sociedade igualitária e pluralista de direitos, cujos direitos devem ser valer para os casais homossexuais assim como para os heterossexuais. Por fim, encerra-se a discussão de efetivar direitos, pondo em questão a esfera do reconhecimento do direito previdenciário em nível nacional como um próximo passo para a nova geração dos direitos decorrentes da dignidade e necessidade humana.

\section{REFERÊNCIAS}

BAEZ, Narciso Leandro Xavier; SILVA, Rogério Luiz Nery da; SMORTO, Guido. Os Desafios dos Direitos Humanos Fundamentais na América Latina e na Europa. Joaçaba: Editora Unoesc, 2011.

BAEZ, Narciso Leandro Xavier; CASSEL, Douglass. A Realização e a Proteção Internacional dos Direitos Humanos Fundamentais: Desafios do século XXI. Joaçaba: Editora Unoesc, 2011.

BRANDÃO, Debora Vanessa Caús. Parcerias Homossexuais: Aspectos Jurídicos. São Paulo: Editora Revista Dos Tribunais, 2002.

BRASIL. Acesso a informação. Disponível em: http://www.acessoainformacao.gov. br/acessoainformacaogov/. Acesso em 28 de agosto de 2014.

FARIAS, Cristiano Chaves de. Os alimentos nas uniões homoafetivas: uma questão de respeito à Constituição. IBDFAM. Disponível em: http://www.ibdfam.org.br/?artigo\&artigo $=99$. Acessado em: 11.10.2013.

FILHO, Francisco Carlos Moreira; MADRID, Daniela Martins. A Homossexualidade e a sua História. Disponível em: http://intertemas.unitoledo.br/revista/index.php/ ETIC/article/viewFile/1646/1569. Acessado em: 11.10.2013.

FONTANELLA, Patrícia. União Estável a Eficácia Temporal das Leis Regulamentadoras. Florianópolis: OAB/SC Editora, 2006. 
DIAS, Maria Berenice. União Homoafetiva: Preconceito \& a Justiça. São Paulo: Editora Revista dos Tribunais, 2009.

LÔBO, Paulo. Entidades familiares constitucionalizadas: para além do numerus clausus. In: PEREIRA, Rodrigo da Cunha (coord). Anais do III Congresso Brasileiro de Direito de Família, Família e Cidadania. O novo $C B B$ e a vacatio legis. Belo Horizonte: Del Rey, 2002.

MARTINS, Bruno Sá Freire. O Impacto da União Homo Afetiva na Previdência. Disponível em: http:/www.conjur.com.br/2011-nov-17/impacto-reconhecimento-uniao-homoafetiva-previdencia. Acessado em: 11.10.2013.

RUPRECHT, Alfredo J. Direito da Seguridade Social. São Paulo: LTR, 1996.

VECCHIATTI, Paulo Roberto Iotti. Manual da Homoafetividade: Da possibilidade jurídica do casamento civil, da união estável e da adoção por casais homoafetivos. Rio de Janeiro: Forense; São Paulo: MÉTODO, 2008.

WALINE, Marcel. L'individualisme et le droit. Paris:Domat-Montchrestien, 1945. 